\title{
LATE TERTIARY-QUATERNARY GEOLOGY OF THE SOUTHWESTERN FLORIDA SHELF AND SLOPE
}

\author{
Charles W. Holmes ${ }^{1}$
}

\begin{abstract}
Seismic stratigraphic information obtained during a high-resolution geophysical survey of the southern Florida (south of $26^{\circ} \mathrm{N}$ ) shelf suggests that the modern shelf and slope overlie a karstfied Miocene (?) platform. The platform surface is covered with a lens of late Tertiary-Quaternary sediments which thicken from the central shelf to a maximum of $150 \mathrm{~m}$ at the upper-slope break and thin on the upper slope against a ridgelike outcrop of the Miocene (?) platform. A 8-km wide north-trending double reef complex lies along a central shelf hingeline that separates post-Miocene sediments offshore from the subcropping Miocene (?) which is covered by a veneer of biogenic sand.

Over the thickest post-Miocene section and marking the edge of the modern shelf is a second double-reef complex. The lower reef of this set forms a well-developed 40-m scarp; the upper reef is characterized for most of its extent by a low amplitude ridge. Between the lower reef and the Miocene (?) outcrop, two stratigraphic units are recognized: (1) a lower unit which can be traced under the shelf-edge reefs and is continuous, onlapping the Miocene (?) to the central shelf; and (2) an upper unit which is composed of sediment derived from the reefs and pelagic sources and exhibits evidence of soil creep by the accordian-like morphology in the deeper reaches.

The Miocene (?) ridge, partially covered by younger sediment, trends north along the west-facing slope of the Florida Shelf until it turns east in the Florida straits and is buried by slope material. The reefs that mark the shelf break and central-shelf reefs are also being covered by more recent material in like manner. The age of the reefs are unknown but the stratigraphic position indicates that the shelf-edge reefs are older than the central-shelf reefs. The encroaching recent reefs and associated platform sedimentation are extending the present shelf to the south and west. The reef-forming processes play an important role in the construction of the modern southern Florida shelf.
\end{abstract}

${ }^{1}$ U. S. Geological Survey, Corpus Christi, Texas 